\author{
EUGENIUSZ SAKOWICZ \\ Uniwersytet Kardynała Stefana Wyszyńskiego \\ $w$ Warszawie
}

\title{
EDUKACJA W ISLAMIE - RETROSPEKCJA
}

Nie ma religii bez edukacji. Wszystkie religie, zarówno te z przeszłości, jak i z doby współczesnej wychowują swoich wiernych. Proces edukacji przebiega zarówno w rodzinie, jak i w szkole. Islam podkreśla znaczenie edukacji jako sposobu doskonalenia człowieka. Chcąc poznać dzisiejszy świat islamu należałoby zastanowić się nad jego przeszłością. Pierwsze wieki istnienia islamu przypadały na czas określany przez kulturę Zachodu jako średniowiecze. Ukształtowane wówczas dziedzictwo kulturowe, w tym edukacja, na stałe wpisało się w dzieje tej religii. I chociaż edukacja nie miała charakteru powszechnego, to jednak zawsze podkreślano jej rangę i znaczenie. Wiedza była u muzułmanów w dużej cenie. Warto było - jak mówi tradycja tej religii - przemierzać świat, docierając do różnych miejsc, by spotkać tam nauczycieli posiadających autorytet. Znany jest wśród muzułmanów imperatyw, powtarzany od średniowiecza po dzień dzisiejszy: „Szukajcie wiedzy, chociażby w Chinach!” Muzułmanie cenili nauczycieli jako tych, którzy uczyli życia, postępowania i w ogóle myślenia zgodnie z literą Koranu. Święta księga islamu była zawsze najważniejszym podręcznikiem zdobywania mądrości i poddawania się woli Allaha. Ważną funkcję w kulturze islamu odgrywały szkoły, w tym madrasy (medresy) nauczające dzieci i młodzież prawd wiary i w ogóle religii.

\section{Słowa kluczowe}

Edukacja, islam, madrasy (medresy), Mahomet, nauczyciel, średniowiecze, wiedza. 
Edukacja stanowi niezmiernie ważny ,filar” każdej religii, w tym islamu ${ }^{1}$. Religia poddanych woli Allaha zawsze kładła duży nacisk na edukację $^{2}$ I chociaż dziś w licznych państwach islamu panuje duży stopień analfabetyzmu (szczególnie w Afryce i w niektórych, ubogich państwach Azji), to jednak wiedza zawsze była przez muzułmanów ceniona. Ignorancja traktowana była i jest jako jeden ze stopni prowadzących do niewiary. Człowiek zdobywający prawdziwą wiedzę staje się coraz bardziej pokorny. Poznaje prawdę o sobie, co właśnie jest „znamieniem” pokory. Człowiek prymitywny lekceważy, a nawet prześladuje ludzi mądrych i uczonych. Wynosi się pychą ponad innych, a tym samym skazuje siebie na zagubienie. Muzułmanie wiedzą, że lekceważenie autorytetów nauczycieli jest ostatecznie lekceważeniem samego Boga, który stanowi pełnię mądrości, wiedzy. On jest Miłosiernym i Litościwym Bogiem domagającym się absolutnej subordynacji ze strony tych, których stworzył. Człowiek przyjmujący religię wciąż religii się uczy. W najgłębszym swoim wyrazie religia oznacza stosunek człowieka do Boga. Relacja ta musi być całe życie formowana, kształtowana. Zadanie to wypełniają szkoły prowadzące edukację.

Niniejszy szkic to spojrzenie retrospekcyjne na edukację $\mathrm{w}$ islamie, dokonującą się w czasach średniowiecza. Ukształtowane wówczas dziedzictwo (tradycja) wciąż - w mniejszym czy większym stopniu - jest

\footnotetext{
${ }^{1}$ Por. J. Nosowski, E. Sakowicz, Islam, [w:] Encyklopedia katolicka, t. 7, TN KUL, Lublin 1997, kol. 501-507.

2 Por. E. Sakowicz, Wychowanie w religiach świata, [w:] Leksykon pedagogiki religii, red. C. Rogowski, Wydawnictwo Verbinum, Warszawa 2007, s. 876-891 (na temat wychowania w islamie zob. s. 889-891). Na uwagę zasługują nadto prace magisterskie powstałe pod kierunkiem E. Sakowicz: H. Kaflik, Wychowanie i kształcenie młodego pokolenia muzutmanów - tradycja i współczesność, mps, Wydział Teologiczny UKSW, Warszawa 2008; A. Chudowolska, Dziecko i jego proces wychowania w islamie, mps, Wydział Nauk Pedagogicznych UKSW, Warszawa 2011; Y. Laskazhevskaya, Rodzina i jej wplyw wychowawczy na dziecko w świecie islamu, mps, Wydział Nauk Pedagogicznych UKSW, Warszawa 2011; M. Pawłowska, Edukacja w świecie islamu, mps, Wydział Nauk Pedagogicznych UKSW, Warszawa 2011; B. Stępkowska, Kobieta jako matka $i$ wychowawczyni $w$ islamie, mps, Wydział Nauk Pedagogicznych UKSW, Warszawa 2011. Wszystkie wymienione prace dyplomowe archiwizowane są w Bibliotece Głównej UKSW w Warszawie.
} 
obecne $\mathrm{w}$ procesie edukacji dzieci oraz $\mathrm{w}$ ogóle młodego pokolenia. Edukacja przebiegała wówczas (i wciąż przebiega) na określonych etapach (traktuje o tym punkt pierwszy). Średniowieczna teoria i pragmatyka edukacyjna podkreślała znaczenie zdobywania wiedzy (jest to przedmiotem rozważań w drugim punkcie). Zawsze w świecie islamu nauczyciel odgrywał wyjątkową rolę. Miał - z nadania samego Boga - autorytet osoby przekazującej wiedzę oraz wychowującej. Autorytet ten był niepodważalny (piszę o tym w punkcie trzecim). W epoce średniowiecza rolę wyjątkową odgrywały madrasy (medresy) - instytucje nauczające religii (przedstawiam tę sprawę w ostatnim, czwartym punkcie).

W tym miejscu trzeba wyraźnie podkreślić, iż słowo „średniowiecze” odnosi się w niniejszym tekście do epoki tak określonej przez historiografię kultury Zachodu. Wielu badaczy porównujących czas średniowiecza europejskiego z czasem rozwoju powstałej w VII wieku religii islamu twierdzi, iż dopiero teraz następuje islamski „wiek średni”. W niniejszym studium dystansuję się od takiej interpretacji tego kluczowego pojęcia. Mówiąc o „średniowieczu islamu”, kieruję się chronologią naszej ery, a nie czasem według kalendarza islamu, uważającego 622 rok, rok hidżry ${ }^{3}$ (emigracji, wywędrowania Mahometa z Mekki do Medyny), za początek ery muzułmańskiej. W tekście posługujemy się też współczesnymi pojęciami, takimi jak np.: „system oświatowy”, „kolegia”, „uczelnia”, „fakultet”, „szkolnictwo wyższe”, mówiąc o czasie, kiedy takie określenia nie funkcjonowały.

\section{ETAPY EDUKACJI}

Islam jest - podobnie jak chrześcijaństwo i judaizm - „religią księgi”. Autorytet tej religii oparty jest na objawionym przez Boga „piśmie”. Centralne miejsce w wierzeniach muzułmanów zajmuje Koran ${ }^{4}$. Istnieją również inne teksty religijne, które stanowią w pewnym sensie „komen-

\footnotetext{
3 Por. E. Sakowicz, Hidżra, [w:] Encyklopedia katolicka, t. 6, TN KUL, Lublin 1993, kol. 836.

4 Por. J. Nosowski, S. Mojek, Koran, [w:] Encyklopedia katolicka, t. 9, TN KUL, Lublin 2002, kol. 827-829.
} 
tarz" do świętej, objawionej Mahometowi przez Allaha księgi. Są to zbiory zwane hadisami ${ }^{5}$, prezentujące opowieści o nauczaniu i czynach Proroka Mahometa oraz jego towarzyszy, a także słowa tego, który stał się ,pieczęcią proroków”. Znane są też liczne komentarze dotyczące nie tylko Koranu, ale i hadisów. Tradycja islamska (sunna) jest zatem tradycją opartą na tekstach, wpierw przekazywanych ustnie i ,przechowywanych" w zbiorowej pamięci, a następnie utrwalonych na piśmie. Fakt ten przyczynił się do nadania nauce i edukacji w islamie szczególnego znaczenia $^{6}$.

W centrum islamskiej edukacji znajdował się zawsze i wciąż się znajduje Koran uważany za źródło wszelkiej wiedzy. Od szóstego roku życia, kiedy to dziecko rozpoczynało naukę w szkole, prawie cały jego „szkolny wysiłek" koncentrował się na zapamiętywaniu wersetów Koranu. Podstawową techniką przyswajania na pamięć świętego tekstu było wielokrotne powtarzanie jego fragmentów za recytującym nauczycielem. Czyniono to tak długo, aż dany passus „wpisał” się do pamięci dziecka, po czym przechodzono do kolejnych wersetów. Pomocne w zapamiętywaniu było kołysanie się w przód i w tył w trakcie recytacji. Celem edukacji było wychowanie dzieci i młodego pokolenia na dobrych muzułmanów, potrafiących wiernie recytować odwieczny Koran. Samo rozumienie recytowanego tekstu było celem drugorzędnym ${ }^{7}$.

Na kolejnych szczeblach edukacji uczenie się tekstów na pamięć zajmowało nadal ważną pozycję. Z większą wnikliwością jednak analizowano niektóre fragmenty świętej księgi oraz podane w niej reguły postępowania. Często np. nauczyciel dyktował określony fragment wyjęty czy to z Koranu, czy z innego dzieła, po czym objaśniał go słuchaczom. Uczniowie sporządzali notatki, których potem uczyli się na pamięć. W celu lepszego zapamiętania obszernego materiału stosowano nastę-

\footnotetext{
5 Por. E. Sakowicz, Hadith, [w:] Encyklopedia katolicka, t. 6, TN KUL, Lublin 1993, kol. 455.

6 Por. J. Berkey, Education, [w:] Encyclopedia of Islam and the Muslim Word, t. 1, red. R. C. Martin, New York 2004, s. 202.

7 Por. J. S. Szylowicz, Education. Educational Methods, [w:] The Oxford Encyclopedia of the Modern Islamic Word, t. 1, red. J. L. Esposito, New York-Oxford 1995, s. 416-417.
} 
pujące techniki: 1) głośno powtarzano lekcje aż „do skutku” (czytanie po cichu było źle widziane); 2) przepisywano liczne ważne teksty w formie wierszowanej ${ }^{8}$.

Ostatecznym celem nie było jednak tylko zdobycie umiejętności powtarzania tekstu, ale rozumienie go. Od uczniów oczekiwano wprawdzie zdobywania wiedzy w sposób „mechaniczny”, ale jednocześnie liczono na wypracowanie umiejętności zastosowania zdobytej wiedzy do konkretnych sytuacji życiowych. Oczekiwano od uczniów również nauki technik argumentacyjnych, którymi posługiwali się autorzy tekstów. W procesie edukacji odwoływano się to dyskusji i dysputy, jednakże „podążały one utartymi szlakami” i skupiały się raczej na sprawach roztrząsanych od wielu generacji, a nie na kwestiach doraźnych. Nauka pozostawała jednak ,zamkniętym” systemem, do którego przenikanie nowych idei było raczej znikome 9 .

Z czasem edukacja stawała się coraz bardziej zinstytucjonalizowana, szczególnie na wyższych szczeblach. Zaczęły się pojawiać różne typy „kolegiów” („uczelni”, „fakultetów”). Kolegia te zachowały nieformalny charakter. Np. słynny egipski meczet-uniwersytet Al-Azhar nie posiadał harmonogramu zajęć. Nie stawiano żadnych wymogów przy wpisywaniu się na uczelnię. Nie określano formalnych edukacyjnych standardów. Nie wyznaczano też obowiązkowych zajęć. Nie przeprowadzano sprawdzianów weryfikujących zdobytą wiedzę. Co więcej, nie czyniono jasnego rozgraniczenia między kadrą a uczniami - ta sama osoba, która na jednych zajęciach była nauczycielem, mogła być uczniem (studentem) w ramach innego wykładu ${ }^{10}$.

Trzeba w tym miejscu podkreślić, że sztuka czytania i pisania, która istniała $\mathrm{w}$ Arabii w ograniczonym zakresie jeszcze przed pojawieniem się islamu, zyskała wysoką rangę wraz z nastaniem tej religii. $\mathrm{W}$ pierwszych latach istnienia islamu nauczycielami w ośrodkach nauki na poziomie podstawowym (kuttab) byli - notabene - również niemuzułmanie (chrześcijanie i Żydzi). Elementarna szkoła kuttab do dnia dzi-

\footnotetext{
8 Por. tamże, s. 417.

9 Por. tamże.

10 Por. tamże.
} 
siejszego jest w niektórych krajach muzułmańskich jedynym ośrodkiem nauczania.

Kiedy Koran oraz nauki Mahometa stały się podstawowym „materiałem" wykorzystywanym w przekazywaniu wiedzy religijnej, sytuacja taka okazała się kontrowersyjna. Zaczęto zastanawiać się nad „słusznością" nauczania świętej księgi przez niemuzułmanów i przekazywania jej treści muzułmanom. Spór na temat tego zagadnienia trwał przez dwa pierwsze stulecia istnienia islamu ${ }^{11}$.

Nauczanie podstawowe stanowiło „samowystarczalną” jednostkę. Nie istniała między nim a „szkolnictwem wyższym” jakaś organiczna więź. Traktowanie edukacji podstawowej jako integralnej części „,hierarchicznego" systemu edukacji, stanowiącej niezbędne oparcie dla szkolnictwa wyższego, jest zjawiskiem współczesnym. Celem średniowiecznego islamskiego systemu edukacji było rozwinięcie do maksimum intelektualnych talentów nie wszystkich dzieci, lecz w gruncie rzeczy tylko niektórych, mimo iż imperatyw edukacji miał wymiar uniwersalny ${ }^{12}$.

Oprócz szkolnictwa podstawowego i wyższego, od wczesnych lat islamu istniały jeszcze inne rodzaje edukacji. Jednym $\mathrm{z}$ nich była edukacja dworska, ustanowiona na użytek książąt, z myślą o przygotowaniu ich do objęcia władzy. Obejmowała ona edukację religijną, ale kładła nacisk m.in. na krasomówstwo, literaturę i przede wszystkim na wartości ważne dla mężczyzny. Kształtowano zatem męskość jako cnotę, czyli stałe usposobienie do podejmowania czynów godnych mężczyzny. Inny znany wówczas rodzaj edukacji można określić „edukacją dla dorosłych”, bądź „edukacją dorosłych”. Miała ona charakter powszechny. Jej celem było nie tyle nauczenie ,ludu” sztuki czytania i pisania, co przekazanie im wiedzy o Koranie i zasadach wiary. To właśnie z tego drugiego rodzaju edukacji wywodzą się wyższe szkoły, utworzone z kręgów studentów zgromadzonych wokół niektórych nauczycieli ${ }^{13}$.

\footnotetext{
11 Por. F. Rahman, Islam, University of Chicago, Chicago-London 1979, s. 181.

12 Por. tamże, s. 181-182.

13 Por. tamże, s. 182.
} 


\section{ZNACZENIE ZDOBYWANIA WIEDZY}

Wysokie znaczenie nauki, uczenia się i w ogóle wiedzy, znajduje swe odbicie w wyżej wskazanych hadisach. Prorok islamu, ceniąc znaczenie edukacji, miał dać swoim uczniom imperatyw: „Szukajcie wiedzy, chociażby w Chinach!" Nakaz ten skierowany został w pierwszej kolejności do uczonych, którzy całe swoje życie poświęcili poszukiwaniu prawdy i jej zgłębianiu. Niemniej jednak dotyczył również wszystkich muzułmanów.

Sam bowiem przekaz nauki zawartej w świętych fragmentach Koranu i w ogóle upowszechnianie wiedzy było tradycyjnie postrzegane przez muzułmanów jako rodzaj praktyki religijnej, jako specyficzna forma kultu. Znalazło to m.in. wyraz w przekonaniu, iż wierny nie powinien rozpoczynać lektury Koranu bez uprzedniego dokonania ablucji (czyli rytualnego obmycia) podobnej do tej, która poprzedza modlitwę ${ }^{14}$.

Pochodzący z XIII wieku traktat o nauce i nauczaniu (autorstwa Burhana al-Din al-Zarnuji) kładł nacisk na znaczenie edukacji w życiu pobożnego muzułmanina. Dzieło to zamykają znamienne słowa: „Wszystkim zalecane jest zdobywać wiedzę”. Trudno jest dziś oszacować liczbę wykształconych muzułmanów czasów średniowiecza. Nie sposób też udzielić dokładnej odpowiedzi na pytanie, co oznaczało w ówczesnym kontekście bycie „wyedukowanym” czy „wykształconym”. Niemniej pewnym jest, że społeczeństwa ówczesnej epoki osiągnęły (w porównaniu z przednowożytnymi społeczeństwami europejskimi) relatywnie wysoki stopień umiejętności czytania i pisania, jak również zaznajomienia się z tekstami przekazującymi określoną wiedzę. Edukacja była w znacznej mierze domeną mężczyzn. Dostępne źródła historyczno-biograficzne dowodzą, że spotkać można było również kobiety, które zdobywały wykształcenie w zakresie religii, niejednokrotnie zyskując (dzięki osiągniętej i wypracowanej mądrości) sławę i uznanie ${ }^{15}$.

\footnotetext{
${ }^{14}$ Por. J. Berkey, dz. cyt., s. 202

15 Por. tamże.
} 
„Wiedza”, jakiej powinni szukać i którą powinni zdobywać muzułmanie, w języku arabskim określana jest terminem 'ilm (liczba mnoga 'ulum). Słowo to może oznaczać każdy rodzaj wiedzy. Niemniej jednak w tradycyjnym kontekście odnosi się ono do wiedzy zdobytej w ramach konkretnego procesu jej przekazywania, przede wszystkim w dziedzinie, którą nazwać by można „religijną”. W tym węższym znaczeniu „wiedza”, a właściwie „nauka teologii” ( 'ilm), stanowi fundament i legitymizację autorytetu ulemów - grupy uczonych mężów, których można by nazwać teologami. Słowo ich określające etymologicznie powiązane jest z terminem 'ilm i oznacza dosłownie: „ci, którzy wiedzą”. Ulemowie mają za zadanie przekazywanie nauk religijnych. W średniowiecznych społecznościach islamskich w skład grupy ulemów wchodzili ludzie, których pozycja wymagała zdobycia wysokiej wiedzy (wykształcenia) właśnie z zakresu religii. Byli to m.in.: sędzia muzułmański (kadi), który rządził społecznością zgodnie z prawem islamskim (urząd kadiego powstał w wyniku przekazania przez kalifów pewnych zakresów władzy sądowniczej uczonym specjalizującym się w zakresie prawa); nauczyciel madrasy (mudarris), który przekazywał nauki religijne młodym generacjom uczonych oraz kaznodzieja (khatib) wygłaszający kazanie w czasie piątkowej modlitwy w meczecie ${ }^{16}$.

„Pochodzenie społeczne” ulemów oraz ich status różnił się znacząco. Niemal każdy mógł nim zostać pod warunkiem, że zdobył odpowiednio głęboką wiedzę i - co za tym idzie - szacunek społeczności. Stanowili oni najważniejszą grupę tradycyjnych, islamskich społeczności i z tego tytułu uważano ich niekiedy za „następców proroków”, za „spadkobierców" autorytetu religijnego, arbitrów tradycji religijnej. Żyjący w XIV wieku jurysta Ibn al-Hadżdż z Kairu zanotował, że „kiedy umierał prawdziwy uczony, płakało po nim całe stworzenie, również ptaki powietrzne i ryby morskie ${ }^{17}$.

W islamie pierwotnym oraz średniowiecznym nie istniało rozróżnienie między tym, co „świeckie” (profanum) i tym, co „święte” (sacrum).

\footnotetext{
16 Por. tamże, s. 202-203

17 Por. tamże, s. 203.
} 
Mimo to, muzułmanie świadomi są istnienia różnicy między tymi „,przestrzeniami” życia czy nauk, które „odziedziczyli” po cywilizacjach przedislamskich (m.in. filozofii, astronomii, medycynie) a innymi, bezpośrednio związanymi z objawieniem koranicznym. O tych pierwszych „przestrzeniach” mówiono: „nauki przodków” lub „nauki racjonalne”. Przez wiele wieków nauki te kwitły w świecie islamu. Poświadczają to wybitni uczeni muzułmańscy: „fizyk” i filozof Ibn Sina (zm. w 1037 r. n.e.), znany na Zachodzie jako Awicenna oraz filozof, teolog i znawca nauk przyrodniczych, Ibn Rushd (zm. w 1198 r. n.e.), znany jako Awerroes ${ }^{18}$

Proces przekazywania kolejnym pokoleniom posiadanej przez nauczycieli wiedzy stanowił część „systemu oświatowego" istniejącego w średniowiecznym islamie. W niektórych przypadkach edukacja wspierana była przez instytucje, z których najsłynniejszą była Bajt al-Hikma, czyli „Dom Mądrości” ustanowiony w IX wieku w Bagdadzie przez kalifa abbasydzkiego Al-Mamuna. Pracowali w nim uczeni islamu: lekarze, matematycy, astronomowie. W instytucji tej thumaczono na język arabski greckie oraz syryjskie filozoficzne dzieła. Inną słynną instytucją wspierającą rozwój i upowszechnianie nauki był (wspomniany wyżej) uniwersytet Al-Azhar, ustanowiony w X wieku w Kairze, przez kalifa fatymidzkiego Al-Hakima. Nauka przekazywana była głównie w sposób nieformalny, z nauczyciela na ucznia ${ }^{19}$.

Edukacja muzułmanów - jak wyżej zaznaczono - rozpoczynała się we wczesnym dzieciństwie. Pierwszym jej stopniem była nauka języka arabskiego i poznawanie Koranu, w tym nauka fragmentów, bądź też całej świętej księgi na pamięć. Nauka ta mogła odbywać się w domu, bądź w szkole - na co wcześniej zwrócono uwagę - znanej pod nazwą kuttab, często znajdującej się przy meczecie. Kuttaby rozwinęły w pierwszym wieku istnienia islamu i w wielu miejscach przetrwały aż do czasów współczesnych, niekiedy konkurując ze szkołami oferującymi bardziej nowoczesny program nauczania ${ }^{20}$.

\footnotetext{
18 Por. tamże.

19 Por. tamże.

20 Por. tamże.
} 
Po odpowiednim przyswojeniu tekstu Koranu, niektórzy uczniowie poszerzali zakres zdobywanej wiedzy. Podejmowane tematy dotyczyły m.in. kwestii poruszanych w hadisach, nadto w komentarzu koranicznym (ta$f$ sir) i przede wszystkim w doktrynie prawnej (fikh). Najważniejszą z nauk religijnych była jurysprudencja, z racji decydującego znaczenia, jakie miało prawo islamskie zarówno w kwestiach kultu, jak również w kwestiach dotyczących postępowania muzułmanów w wymiarze społecznym oraz politycznym. Również na tym etapie edukacji zapamiętywanie odgrywało ważną rolę. Średniowieczne źródła islamskie opisują mędrców znających na pamięć tysiące hadisów i innych tekstów. Jednak od zaawansowanego adepta nauk religijnych wymagano znacznie więcej, niż dobrej pamięci.

Dwie rzeczy zasługiwały na szczególną uwagę. Po pierwsze, nauka (studia) przygotowywała studenta do uczestniczenia, jako czytelnik lub autor, w „zazębiającym się” układzie tworzącym korpus tekstów i komentarzy do tekstów. W rzeczywistości przygotowywała ona studenta do włączenia się w „dialog” lub „dyskurs” stanowiący istotę życia intelektualnego ulemów. „Dialog” ten, charakteryzujący się żarliwością, jest dość dobrze udokumentowany dzięki tekstom pozostawionym przez ulemów żyjących we wczesnych wiekach islamu. Po drugie, „studia wyższe” wiązały się z procesem ,uspołecznienia”, w trakcie którego uczący się stopniowo zdobywał coraz wyższy status w oczach innych uczonych. W związku z tym, że nie istniała instytucja kapłaństwa ani żaden inny formalny system „stopni” wtajemniczenia w życie religijne, ten element procesu edukacji odgrywał bardzo ważną rolę. Uczeń mógł zatem związać się z jednym lub większą liczbą nauczycieli, tym samym rozwijając z nimi personalne i intelektualne relacje ${ }^{21}$.

\section{AUTORYTET NAUCZYCIELA}

Kluczem do zrozumienia genezy islamskiego nauczania, jego rozwoju i rozpowszechnienia się we wczesnych latach islamu są nie tyle szkoły, co konkretne osoby - nauczyciele. W początkach systemu edukacyj-

\footnotetext{
21 Por. tamże.
} 
nego islamu ważne były indywidualne poszukiwania. Niektóre wybitne osobistości, które poznały tradycję i zbudowały na tym fundamencie swoje własne systemy prawne i teologiczne, przyciągały uczniów, którzy przybywali niekiedy z daleka, by czerpać od nich wiedzę. Pierwszą i podstawową cechą charakterystyczną dla tego nauczania, która przetrwała przez cały okres „,islamskiego średniowiecza”, było jednostkowe (indywidualne) znaczenie nauczyciela. Po przeprowadzeniu całego kursu, nauczyciel osobiście wystawiał studentowi certyfikat, co dawało studentowi uprawnienia do nauczania w zakresie danego przedmiotu. Niekiedy certyfikat ten dotyczył pojedynczego tematu - np. fikh lub hadisów. Czasem dotyczył kilku tematów, ale mógł też ograniczać się do kilku książek, które uczeń przeczytał. Później, gdy powstały szkoły - madrasy, ustanowiono system egzaminacyjny. Jednak rola i prestiż nauczycieli była tak duża, że nawet po powołaniu do istnienia madras, biografie znakomitych ludzi i uczonych podają zwykle nauczycieli, u których pobierali oni nauki, pomijając nazwy szkół, do których uczęszczali. Certyfikaty wystawiane były częściej z podaniem imienia konkretnego nauczyciela, a nie z nazwą szkoły. W rzeczy samej, nie byłoby dalekim od prawdy stwierdzenie, że jeszcze pod koniec średniowiecza, większość sławnych erudytów nie było absolwentami madras, tylko nieformalnymi uczniami indywidualnych nauczycieli ${ }^{22}$.

$\mathrm{Z}$ centralnym znaczeniem osoby nauczyciela związany był fenomen zwany „poszukiwaniem wiedzy” (talib al-'ilm). Wędrowni studenci przemieszczali się „wzdłuż i wszerz” świata muzułmańskiego po to, by zdobywać wiedzę przy boku sławnych nauczycieli. Pierwszym i najmocniejszym bodźcem motywującym te „uczone” podróże była nauka hadisów. Znane są świadectwa, według których niektórzy studenci pobierali nauki nawet u 100 nauczycieli. „Przygotowywanie się do drogi” (shadd al-rihăl) stanowiło zdanie-klucz trafnie podsumowujące ten mechanizm zdobywania wiedzy ${ }^{23}$.

\footnotetext{
22 Por. F. Rahman, dz. cyt., s. 184-185.

23 Por. tamże, s. 185.
} 
Nauczyciele cieszyli się ogromnym autorytetem. Koran dawał im prawo do wymierzania kary cielesnej. Użycie rózgi było uważane za niezbędne w trosce o odpowiedni rozwój charakteru ucznia. Na wyższych szczeblach edukacja była mocno zindywidualizowana (,spersonalizowana"), bowiem powszechnie wierzono, iż zdobywanie wiedzy odbywa się poprzez kontakt z osobami, które ją posiadają. Student mógł wybrać sobie mistrza i rozwinąć z nim bliską więź osobistą i intelektualną. Wybór nauczyciela był często najważniejszą decyzją stojącą przed uczniem, gdyż jego przyszła kariera zależała głównie od reputacji, jaką cieszył się jego mentor. Na nauczycielu spoczywała odpowiedzialność za rozwój moralny i intelektualny ucznia. Ich relacja nie była jednak pozbawiona psychologicznego dystansu i nauczyciel miał prawo srogo karać uczniów, z którego to przywileju często - jak wyżej zaznaczono - korzystał ${ }^{24}$.

\section{MADRASY - INSTYTUCJE NAUCZANIA RELIGII}

W pierwszych wiekach islamu przekazywanie wiedzy religijnej odbywało się w nieformalny sposób. Uczeni prowadzili wykłady („lekcje") w meczetach lub w prywatnych domach. Tego typu nieformalne rozwiązania nigdy nie straciły na ważności w procesie przekazywania 'ilm. Jednocześnie, począwszy od przełomu XI i XII wieku, władcy oraz inni wpływowi członkowie społeczności muzułmańskich na Bliskim Wschodzie, zaczęli zakładać wspomniane wyżej instytucje zwane $m a-$ drasami (medresami), poświęcone nauczaniu religii (przede wszystkim zaś jurysprudencji) na zaawansowanym poziomie. Madrasy jako instytucje mogą wywodzić się z Khurasanu we wschodnim Iranie. Szybko przyjęły się one na Bliskim Wschodzie i wpisały się w pejzaż miast i miasteczek w Egipcie, Syrii, Iranie, a później w anatolijskich i bałkańskich prowincjach imperium otomańskiego. Szczególnie ważne miasta, takie jak Kair, mogły poszczycić się dziesiątkami madras, od małych do wielkich. Każda madrasa dysponowała budynkiem, w którym od-

${ }^{24}$ Por. J. S. Szylowicz, dz. cyt., s. 417. 
bywały się lekcje. Były tam pomieszczenia dla jednego lub więcej nauczycieli i pewnej liczby uczniów. Szkoła i jej działalność mogła być wspierana poprzez darowizny (wakf) składane przez fundatora madrasy. Szkoły te różniły się pod względem wielkości oraz „infrastruktury”, co wiązało się z wysokością darowizn przeznaczanych na ich cel. Niektóre zatrudniały wielu nauczycieli i zapewniały uposażenie setkom uczniów, podczas gdy inne wspierały zaledwie kilku ${ }^{25}$.

Rozpowszechnienie się instytucji szkolnych - madrasściśle wiązało się z politycznymi strukturami średniowiecznego świata islamu. Generalnie rzecz biorąc, w średniowieczu na Bliskim Wschodzie władza polityczna charakteryzowała się dosyć znaczącym rozdrobnieniem. Wiele terytoriów, znajdujących się w centrum islamskiego panowania, znajdowało się pod rządami militarnych elit dowodzonych przez cudzoziemca, często Turka lub Mongoła, „świeżo” i powierzchownie nawróconego na islam. Decyzja władców o ufundowaniu i wspomaganiu instytucji służących przekazywaniu islamskich nauk stanowiła strategię mającą na celu zapewnienie wsparcia, a przynajmniej przychylności wobec ulemów, cieszących się znacznym szacunkiem wśród lokalnej ludności muzułmańskiej. W miastach Egiptu i Syrii, madrasy były często „połączone" $\mathrm{z}$ wielkimi grobowcami, wzniesionymi na cześć patronów (mecenasów) szkół. W tym wymownym „połączeniu” szkoły (przyszłość) oraz grobowca (przeszłość) należy się dopatrywać zarówno wymiaru duchowego, jak i politycznego edukacji ${ }^{26}$.

Pomimo dużego znaczenia madras, system przekazywania wiedzy religijnej i kształcenia przyszłych generacji ulemów zachował swój nieformalny charakter, przynajmniej do końca średniowiecza. Średniowieczne źródła obszernie opisują, przy czyim „boku” dana osoba zdobywała wiedzę i z którymi mistrzami utrzymywała zażyłe relacje, ale praktycznie milczą na temat miejsc, w których nauka się odbywała.

Nie istniał oficjalny system ,stopni” (tytułów naukowych). Zastępowały go świadectwa potwierdzające rodzaj i jakość zdobytej edukacji,

25 Por. J. Berkey, dz. cyt., s. 203-204.
26 Por. tamże, s. 204. 
zawarte w ijaza. Ijaza mogła przybierać różne formy: mogło nią być oficjalne poświadczenie mistrza stwierdzające, że dana osoba przestudiowała z nim dany tekst, lub też oświadczenie, że dany uczeń opanował całą dziedzinę wiedzy. W każdym przypadku chodziło o dokument potwierdzający istnienie relacji między uczniem a mistrzem i - w szerszej perspektywie - nauczycielami mistrza. W ten sposób uczeń wpisywał się w genealogię autorytetów, która stanowiła jedyną uznawaną hierarchię w ramach systemu edukacji. W okresie imperium otomańskiego ten luźny i spersonalizowany system ustąpił bardziej wyraźniej nakreślonej strukturze. W Istambule w Turcji istniała hierarchia madras oparta na ocenie sukcesów zawodowych odnoszonych przez wywodzących się z nich uczniów. W innych częściach świata islamu edukacja podążała jednak tradycyjnymi torami, opierając się na nieformalnych wzorcach. W Indonezji głoszenie nauk muzułmańskich (w tym egzegeza Koranu oraz jurysprudencja) miało miejsce $\mathrm{w}$ instytucjach zwanych pesantren. Były one mniej sformalizowane niż bliskowschodnie madrasy. Mogły być odpłatne lub finansowane z jałmużny złożonej przez lokalnych muzułmanów i z innych darowizn. Często zakładane były z inicjatywy indywidualnych uczonych, w związku z czym mogły przestać funkcjonować w momencie śmierci ich założyciela, bądź założycieli27.

Rozpowszechnienie się madras $\mathrm{w}$ średniowieczu miało znaczące konsekwencje społeczne, głównie z racji ich konsolidującego charakteru, pozwalającego różnorodnym społeczeństwom uczestniczyć we wspólnym realizowaniu idei kulturowych (,projekcie kulturowym”). Tendencja ta widoczna była na wielu różnych płaszczyznach. Teksty i metody służące nauczaniu islamskiego prawa i religii były jednolite w całym świecie islamu sunnickiego, dzięki czemu uczeń lub nauczyciel z Iranu (Persji) mógł bez problemu „odnaleźć się” w lokalnej madrasie np. w Damaszku w Syrii czy w Kairze w Egipcie. Zapewniając uczniom stypendia, instytucje te dawały przedstawicielom różnych środowisk możliwość spróbowania sił w mozolnym procesie edukacji, prowadzącym do zdobycia pozycji szanowanego uczonego. Instytucje te przy-

\footnotetext{
${ }^{27}$ Por. tamże.
} 
czyniły się również do szerzenia nauki islamu poza centrami miejskimi, gdzie skupiała się większość ulemów. Były one bowiem otwarte na młodych kandydatów z prowincji, którzy po odpowiednim przeszkoleniu wracali do rodzinnych osad, by tam nauczać i sprawować pieczę nad życiem religijnym w lokalnej społeczności ${ }^{28}$.

Znamienną cechą średniowiecznej edukacji islamskiej był stały i dynamiczny rozwój oficjalnych bibliotek przy meczetach oraz tzw. bibliotek półpublicznych. Wielu wybitnych urzędników gromadziło (kupowało) bogate zbiory książek w celu oddania ich do dyspozycji uczonym, a niekiedy nawet na publiczny użytek. Tak samo postępowali na wpół niezależni władcy księstw i wodzowie w późnym okresie abbasydzkim. Pod koniec X wieku filozof Awicenna uzyskał dostęp do biblioteki ówczesnego władcy perskiego, na której temat wyraził niejedno pochlebstwo, a którą później strawił ogień. Mówiło się, że biblioteka pałacowa wspomnianego wyżej fatymidzkiego władcy Al-Hakima w Kairze składała się z 40 pomieszczeń wypełnionych książkami. Biblioteki te zawierały książki z różnych dziedzin: literatury, nauk przyrodniczych, logiki, filozofii, itd. ${ }^{29}$.

\section{BIBLIOGRAFIA}

Berkey J., Education, [w:] Encyclopedia of Islam and the Mulim Word, t. 1, red. R. C. Martin, New York 2004, s. 202-206.

Chudowolska A., Dziecko i jego proces wychowania w islamie, mps., Wydział Nauk Pedagogicznych UKSW, Warszawa 2011.

Kaflik H., Wychowanie i ksztatcenie młodego pokolenia muzułmanów - tradycja i współczesność, mps., Wydział Teologiczny UKSW, Warszawa 2008.

Laskazhevskaya Y., Rodzina i jej wpływ wychowawczy na dziecko w świecie islamu, mps., Wydział Nauk Pedagogicznych UKSW, Warszawa 2011.

\footnotetext{
28 Por. tamże.

29 Por. F. Rahman, dz. cyt., s. 182.
} 
Nosowski J., Mojek S., Koran, [w:] Encyklopedia katolicka, t. 9, TN KUL, Lublin 2002, kol. 827-829.

Nosowski J., Sakowicz E., Islam, [w:] Encyklopedia katolicka, t. 7, TN KUL, Lublin 1997, kol. 501-507.

Pawłowska M., Edukacja w świecie islamu, mps., Wydział Nauk Pedagogicznych UKSW, Warszawa 2011.

Rahman F., Islam, University of Chicago, Chicago-London 1979.

Sakowicz E., Hadith, [w:] Encyklopedia katolicka, t. 6, TN KUL, Lublin 1993, kol. 455.

Sakowicz E., Hidżra, [w:] Encyklopedia katolicka, t. 6, TN KUL, Lublin 1993, kol. 836.

Sakowicz E., Wychowanie w religiach świata, [w:] Leksykon pedagogiki religii, red. C. Rogowski, Wydawnictwo Verbiunum, Warszawa 2007, s. 876-891.

Stępkowska B., Kobieta jako matka $i$ wychowawczyni $w$ islamie, mps., Wydział Nauk Pedagogicznych UKSW, Warszawa 2011.

Szylowicz J. S., Educational Methods, [w:] The Oxford Encyclopedia of the Modern Islamic World, t. 1, red. J. L. Espozitto, New York-Oxford 1995, s. 416-420.

\section{EDUCATION IN ISLAM - RETROSPECTION}

There is no religion without education. Educating the faithful has been an integral part of all religions in the past as well as in modern times. The education process takes place both in families and at school. Islam emphasises the importance of education as a method of man's development. In order to understand the world of Islam today, one has to examine its past. The first centuries of the existence of Islam coincided with the mediaeval period in Western culture. The cultural heritage developed in that period, including education, became an integral part of Islam. Although education was not universal, its role and importance were always emphasised. Knowledge was valued by Muslims. According to Islamic tradition, it was worth travelling to various places across the world to meet renowned teachers. An injunction known 
among Muslims since the Middle Ages until today says: „Seek knowledge, even in China!" Muslims held teachers in high regard in that they taught people how to live, behave and think in accordance with the Koran. The holy book of Islam was the most important guide to attaining knowledge and submitting to the will of Allah. Schools, including madrasahs, were important places teaching the articles of faith, and religion in general, to children and youth.

\section{Key words}

Education, Islam, madrasah (medrese), Muhammad, teacher, Middle Ages, knowledge. 